\title{
V3 Loop
}

National Cancer Institute

\section{Source}

National Cancer Institute. V3 Loop. NCI Thesaurus. Code C13412.

Third hypervariable region (V3) of the gp120 HIV envelope protein. 